\title{
The digestion of yeast cell wall polysaccharides in veal calves
}

\author{
By BLANCHE D. E. GAILLARD \\ Department of Animal Physiology, Agricultural University, Haarweg 10, \\ Wageningen, The Netherlands \\ AND E. J. VAN WEERDEN \\ ILOB, Institute for Animal Nutrition Research, Haarweg 8, \\ Wageningen, The Netherlands
}

(Received 21 Fanuary 1976-Accepted 8 March 1976)

\begin{abstract}
1. The digestibility of the cell wall polysaccharides of an alkane-grown yeast in different parts of the digestive tract of two veal calves fitted with re-entrant cannulas at the end of the ileum was studied by replacing part of the skim-milk powder of their 'normal', milksubstitute (all-milk-protein) diet by yeast (yeast diet).

2. The lactose and glucose of both the all-milk-protein diet and the yeast diet were almost completely digested before the end of the ileum. During this digestion a small amount of oligosaccharides composed of galactose and glucose was synthesized. These oligosaccharides were digested again in the large intestine.

3. The constituent sugars of the water-soluble fraction of the yeast cell wall carbohydrates were glucose and mannose. The $0.5 \mathrm{M}$-sulphuric acid-hydrolysate of the water-insoluble fraction contained glucose and mannose and the $\mathrm{I}_{2} \mathrm{M}-\mathrm{H}_{2} \mathrm{SO}_{4}$-hydrolysate only glucose.

4. Digestibilities of these fractions over the whole gastrointestinal tract ranged from 0.77 to 0.90 . Digestibilities measured at the end of the ileum varied considerably between the two animals and averaged only about 0.40 .

5. These findings suggest that the cell wall polysaccharides of yeast are digested very little by the normal digestive enzymes of the calf's small intestine, but are used as a substrate by the bacterial flora which are mainly concentrated in the large intestine.
\end{abstract}

From the literature it is well known that veal calves, which during their life of 4-4.5 months are given only a milk-substitute diet, can digest lactose almost completely (Okamoto, Thomas \& Johnson, r959; Velu, Gardner \& Kendall, 1959; Velu, Kendall \& Gardner, r960; Huber, Jacobson, Allen \& Hartman, I96ı ; Gropp, 1973a, $b, c)$.

However, due to the low secretion or even complete absence of the relevant enzymes, they have little or no ability to digest other carbohydrates, such as sucrose, maltose and oligo- or polysaccharides (Okamoto et al. 1959; Velu et al. 1959, 1960; Huber et al. 1961 ; Gropp, 1973a,b,c). Therefore, one could predict that yeast carbohydrates which are found mostly in the cell wall and predominantly consist of polysaccharides such as mannan and glucan, cannot be digested by the normal digestive enzymes of non-ruminating veal calves.

The object of this paper was to study the fate of these yeast carbohydrates inside the intestinal tract of the milk-fed calf. 
Table $\mathrm{x}$. Composition $(\mathrm{g} / \mathrm{kg})$ of the diets given to veal calves

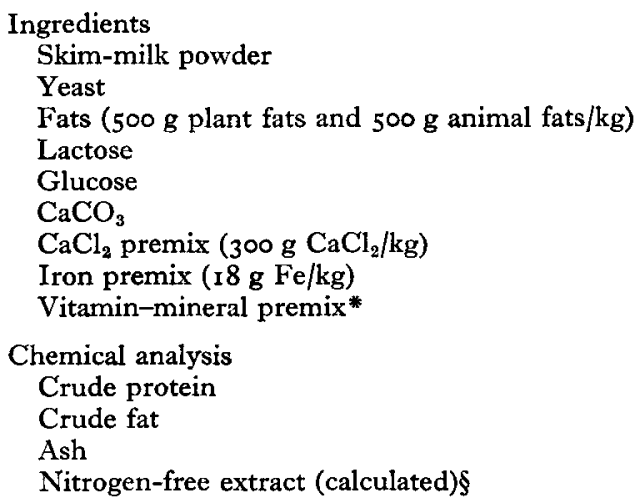

$\begin{array}{cc}\begin{array}{c}\text { All-milk-protein } \\ \text { diet }\end{array} & \text { Yeast diet } \\ 735 & 335 \\ - & 300 \\ 165 & 165 \\ 40 & 84 \\ 47 & 84 \\ - & 10 \\ - & 10 \\ I & - \\ 12 & 12 \\ & \\ 265.8 † & 328.57 \\ 172 & 174 \\ 66 & 64 \\ 465 & 405\end{array}$

* Supplied per $\mathrm{kg}$ diet: I $\mathrm{g} \mathrm{NaCl}$ (iodized), $3.0 \mathrm{~g} \mathrm{CaHPO}, 2 \mathrm{H}_{2} \mathrm{O}, 1 \cdot 5 \mathrm{~g} \mathrm{CaCl}_{2} .2 \mathrm{H}_{2} \mathrm{O}$, I g MgO, $68 \mathrm{mg} \mathrm{ZnO}, 0.4 \mathrm{mg} \mathrm{KI}, 0.12 \mathrm{mg} \mathrm{Na} \mathrm{SeO}_{3} \cdot \mathrm{H}_{2} \mathrm{O}$, $5 \mathrm{mg}$ retinol, $82.5 \mu \mathrm{g}$ cholecalciferol, I7 mg DL- $\alpha-$ tocopheryl acetate, $5.1 \mathrm{mg}$ thiamin, $8.5 \mathrm{mg}$ riboflavin, $0.02 \mathrm{mg}$ cyanocobalamin, $3.4 \mathrm{mg}$ pyridoxine, $21 \mathrm{mg}$ calcium pantothenate, $34 \mathrm{mg}$ niacin, $68 \mathrm{mg}$ ascorbic acid, $5.1 \mathrm{mg}$ menaphthone, $34 \mathrm{I} \mathrm{mg}$ choline chloride, $75 \mathrm{mg}$ penicillin-streptomycin, $50 \mathrm{mg}$ furazolidone (Orphahell BV, Amsterdam, The Netherlands).

$+\mathrm{N} \times 6.38$.

\pm Milk- $\mathrm{N} \times 6.38$ and yeast- $\mathrm{N} \times 6 \cdot 25$.

$\S$ Calculated as dry matter $-($ crude protein + crude fat + ash $)$.

\section{EXPERIMENTAL}

\section{Design of the experiment}

Two calves were each fitted with a re-entrant cannula at the end of the ileum. In the first period of the experiment both animals, which were then about to weeks of age and weighed about $95 \mathrm{~kg}$, were given a 'normal', all-milk-protein diet with $735 \mathrm{~g}$ skimmilk powder/kg dry matter (DM) (Table I). Each calf was given daily $4.1 \mathrm{l}$ milk at a concentration of $150 \mathrm{~g}$ dry powder $/ 1$ milk. In the second period of the experiment, when the calves were about $\mathrm{I} 3$ weeks old, a diet containing $300 \mathrm{~g}$ alkane-grown yeast/ $\mathrm{kg} \mathrm{DM}$ (yeast diet) was given ('Table I). In this period each calf received daily 4.51 milk at the same DM concentration as in the first period. This yeast contained $68 \mathrm{I} \mathrm{g}$ crude protein (nitrogen $\times 6 \cdot 25$ ) and $198 \mathrm{~g} \mathrm{~N}$-free extract $(\mathrm{NFE}) / \mathrm{kg}$. The NFE content of the all-milk-protein diet was calculated to be $465 \mathrm{~g} / \mathrm{kg}$ DM, i.e. $4 \mathrm{I} 8 \mathrm{~g}$ lactose and $47 \mathrm{~g}$ glucose/kg DM; the NFE content of the yeast diet (/kg DM) was estimated at $405 \mathrm{~g}$, consisting of $59 \mathrm{~g}$ yeast-NFE, $262 \mathrm{~g}$ lactose and $84 \mathrm{~g}$ glucose.

In each period of the experiment the digestibility of the diet was determined. Digestibility was measured in two different ways, first in the normal way by analysis of the faeces and secondly by analysis of the ileal contents. With the first method digestibility was measured over the whole gastrointestinal tract (abomasum + small intestine + large intestine), whereas with the second method digestibility was estimated for the part of the gastrointestinal tract ending at the end of the small intestine (abomasum + small intestine). In this way the fate of carbohydrates in the first (abomasum 
+ small intestine) and the second (large intestine) part of the intestinal tract could be determined separately.

For the determination of digestibility over the whole gastrointestinal tract, faeces were collected quantitatively for a period of $4 \mathrm{~d}$. The determination of digestibility through the abomasum and small intestine involved a quantitative collection of ileal contents also for $4 \mathrm{~d}$. This collection was made $\mathrm{I}$ week after the collection period for the faeces. The chyme draining from the opened proximal end of the re-entrant cannula was collected and weighed each hour. An equal amount by weight of a mixture of faeces and physiological saline solution ( $9 \mathrm{~g}$ sodium chloride $/ \mathrm{l})(\mathrm{c} .80 \mathrm{~g} \mathrm{DM} / \mathrm{kg}$ ) was poured back into the distal end of the cannula each hour. The quantitatively collected faeces and chyme were stored at $0^{\circ}$ until they were analysed.

\section{Chemical analyses}

Diets, faeces and ileum chyme were analysed for $\mathrm{DM}$, ash, $\mathrm{N}$ and crude fat according to standard methods: DM by drying in an oven at $\mathrm{IOI}^{\circ}$ to constant weight; ash by incineration at $550^{\circ}$ for $4 \mathrm{~h}$; total $\mathrm{N}$ in the fresh material by using a Technicon AutoAnalyzer (Technicon Instruments Co. Ltd, Basingstoke, Hants) after wet digestion with a solution of $c$. $2 \cdot 0 \mathrm{M}$-potassium sulphate in $\mathrm{I} 8 \mathrm{M}$-sulphuric acid and selenium as a catalyst; crude fat by digestion for $\mathrm{I} h$ with $3 \mathrm{M}$-hydrochloric acid, drying for $3 \mathrm{~h}$ under vacuum at $100^{\circ}$, followed by $8 \mathrm{~h}$ extraction with diethyl ether; $\mathrm{NFE}$ contents were calculated as $\mathrm{DM}-(\mathrm{ash}+\mathrm{N} \times 6 \cdot 25+$ crude fat $)$.

The carbohydrates were analysed in four fractions (Fig. I).

Fraction I. The starting material was boiled twice under reflux with ethanol-water $(80: 20, v / v)$; the mono-, di- and oligosaccharides were thus dissolved. After centrifugation, the ethanolic solution was concentrated under reduced pressure to a small volume, $\mathrm{H}_{2} \mathrm{SO}_{4}$ was added to $0.5 \mathrm{M}$ and di- and oligosaccharides hydrolysed by boiling for $4 \mathrm{~h}$ under reflux.

Fraction 2. The residue was boiled with water under reflux for 4 h. After centrifuging, $\mathrm{H}_{2} \mathrm{SO}_{4}$ was added to the solution to $0.5 \mathrm{M}$ and hydrolysed for $4 \mathrm{~h}$.

Fraction 3. The residue obtained after water extraction was hydrolysed with 0.5 $\mathrm{M}-\mathrm{H}_{2} \mathrm{SO}_{4}$ for $4 \mathrm{~h}$ and the hydrolysate separated from the residue.

Fraction 4 . The residue was washed with acetone and dried overnight. It was then treated with $3-5 \mathrm{ml}$ I $2 \mathrm{M}-\mathrm{H}_{2} \mathrm{SO}_{4}$ at $20 \pm 2^{\circ}$. The mixture was stirred frequently with a glass rod and all lumps carefully broken up. After 4 h the mixture was diluted with I r vol. water and further hydrolysed in a boiling water-bath for $6 \mathrm{~h}$.

In the hydrolysates total sugars were estimated after neutralization by the ferricyanide method of Hagedorn \& Jensen (1923). For the determination of the relative amounts of the constituent sugars, portions of the hydrolysates were neutralized with barium carbonate. The solutions were concentrated under reduced pressure and the sugars separated by descending chromatography on SS paper $2040^{\mathrm{a}}$ (Carl Schleicher \& Schull, Dassel, Germany) with butanol-ethanol-water (7:2:2 by vol.) as the developing solvent and aniline phosphate in ethanol as the indicator. The amounts of individual sugars were determined by the method of Hagedorn \& Jensen (1923) after elution of the approporiate zones of the chromatogram with water. 


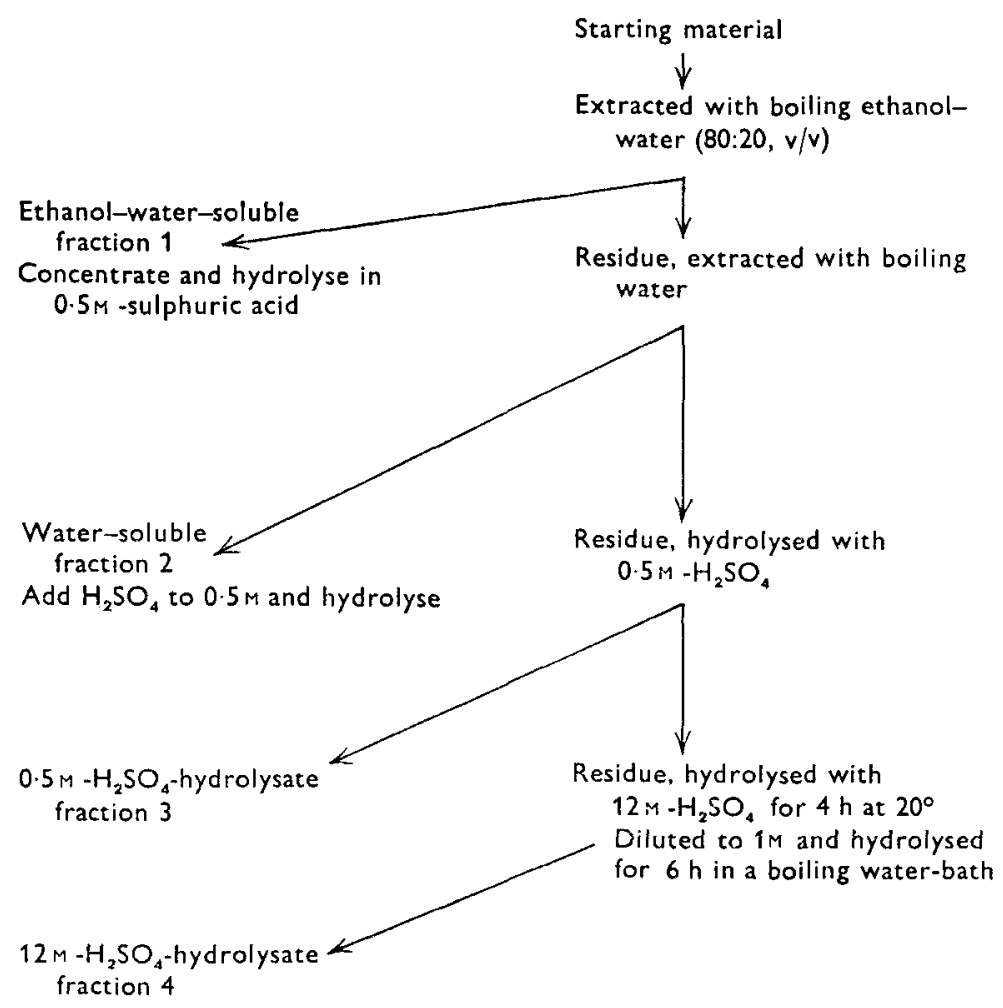

Fig. I. Fractionation of the carbohydrates of diets, faeces and ileal contents of calves given milk-substitute diets with and without yeast.

Fractions nos. 2, 3 and 4 from the period on the all-milk-protein diet were insignificant. Therefore, determinations of constituent sugars were not made in these fractions or in the corresponding ones of the ileal digesta and the faeces.

As the all-milk-protein and yeast diets contained a large amount of fat, they were first extracted with diethyl ether.

Amounts of all sugars were expressed as $\mathrm{g}$ anhydrosugars $/ \mathrm{kg}$ 'original' DM (i.e. $\mathrm{DM}$ in starting material).

\section{RESULTS AND DISCUSSION}

The appetite of both calves was normal and no distinct influence of the diet on faeces consistency was found.

The digestibility coefficients for organic matter and NFE of the two diets are given in Table 2 for each calf separately.

When measured over the whole gastrointestinal tract, there was not much difference between the digestibility coefficients of the NFE fractions of the two diets (average values 0.99 and 0.98 respectively); however, when measured at the end of the ileum, there was a difference of about $10 \%$ (average values 0.93 and 0.83 respectively).

Thus with the all-milk-protein diet the carbohydrate fraction (lactose and some glucose) was already $93 \%$ digested and absorbed in the small intestine and almost 
Table 2. Ileal and faecal digestibility coefficients of organic matter and nitrogen-free extracts (NFE) for two veal calves given milk-substitute diets* with or without $300 \mathrm{~g}$ yeast $/ k g$

\begin{tabular}{cccccc}
\multirow{4}{*}{ Organic matter } & Calf no. & $\overbrace{\text { Faecal }}^{\text {All-milk-protein diet }}$ & Ileal & $\overbrace{\text { Faecal }}^{\text {Diet with }}$ & Ileal \\
& I5 & 0.99 & 0.95 & 0.94 & 0.89 \\
NFE & 16 & 0.98 & 0.94 & 0.93 & 0.85 \\
& Mean & 0.98 & 0.94 & 0.93 & 0.87 \\
& 15 & 0.99 & 0.93 & 0.98 & 0.86 \\
& 16 & 0.99 & 0.93 & 0.98 & 0.81 \\
& Mean & 0.99 & 0.93 & 0.98 & 0.83 \\
& & * For details, see Table 1. & &
\end{tabular}

Table 3. Ileal and faecal digestibility coefficients of the nitrogen-free extract of the yeast added at $300 \mathrm{~g} / \mathrm{kg}$ to milk-substitute diets* fed to two veal calves

\begin{tabular}{ccc} 
Calf no. & \multicolumn{2}{c}{ Digestibility } \\
I5 & 0.90 & Ileal \\
I6 & 0.94 & 0.46 \\
Mean & 0.92 & 0.07 \\
\multicolumn{2}{l}{ * For details, see Table } & 0.26
\end{tabular}

completely digested by the time it reached the end of the intestinal tract. With the yeast diet, however, digestion of the NFE fraction amounted only to about $84 \%$ by the end of the ileum, but equalled that of the all-milk-protein diet $(98 \%)$ by the end of the intestinal tract.

If we assume that in the yeast diet the digestibility of lactose and glucose was not influenced by the presence of yeast in the experimental diet, that the NFE fractions were composed only of carbohydrates, and that the carbohydrate content of the yeast was about $200 \mathrm{~g} / \mathrm{kg}$, then the digestibility of the yeast-NFE can be calculated (Table 3).

The results indicate that the faecal digestibility coefficient of the yeast-NFE was about 0.92 , but the ileal digestibility coefficient was only 0.46 in one calf and 0.07 in the other.

To verify the assumptions made, the amounts of each carbohydrate fraction (Fig. I) and of individual carbohydrates in the diets, digesta and faeces were determined. The results are given in Table 4.

In both diets lactose and glucose were the only ethanol-water $(80: 20, \mathrm{v} / \mathrm{v})$-soluble sugars. The yeast-carbohydrates were found in fractions nos. 2, 3, and 4. Fractions nos. 2 and 3 both contained glucose and mannose but in different relative proportions. In fraction no. 2 the value for mannose: glucose was $5.3: x$ and in fraction no. 3 it was I: 1 . Fraction no. 4 contained only a glucan.

The amounts of carbohydrates consumed and digested by calves on both diets are 
Table 4. Amounts of the different carbohydrate fractions ( $\mathrm{g} / \mathrm{kg}$ dry matter) in a yeast, and in milk-substitute diets* with and without $300 \mathrm{~g}$ yeast $/ \mathrm{kg}$ fed to two veal calves

Fraction no.†

I Ethanol-water-soluble

2 Water-soluble

$30.5 \mathrm{M}$-sulphuric acidhydrolysate

4 I2 $\mathrm{M}-\mathrm{H}_{2} \mathrm{SO}_{4}$-hydrolysate
All-milk-protein

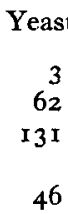

Diet with $300 \mathrm{~g}$

diet

432

4

2

一 yeast $/ \mathrm{kg}$

* For details, see Table r.

+ For details of fractions and fractionation procedure, see Fig. 1 .

Table 5. Ileal digestibility coefficients of the different carbohydrate fractions and of their constituent sugars for two veal calves given milk-substitute diets* with and without $300 \mathrm{~g}$ yeast $/ \mathrm{kg}$

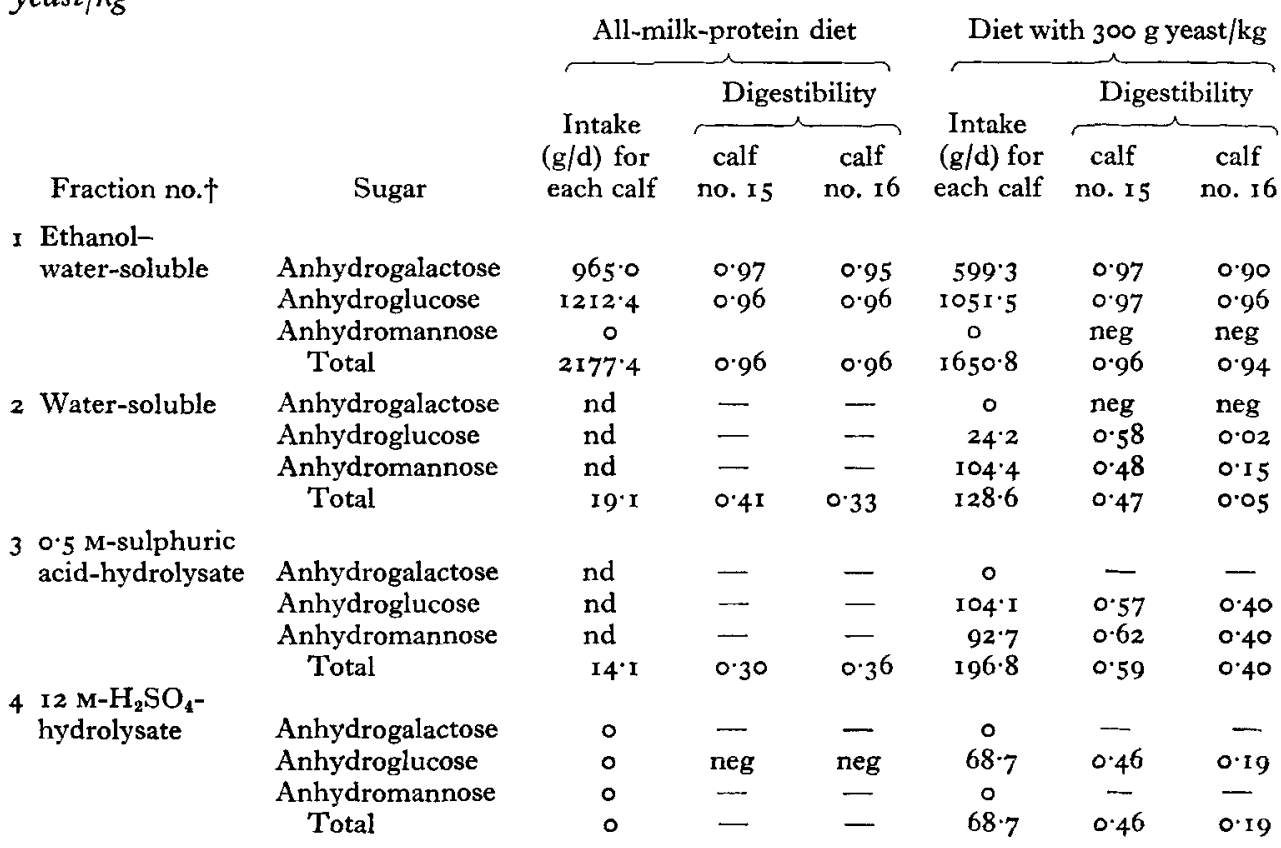

neg, negligible secretion of this sugar into the gastrointestinal tract; nd, not determined.

* For details, see Table 1 .

+ For details of fractions and fractionation procedure, see Fig. I.

given in Tables 5 and 6 together with the digestibility coefficients of the different carbohydrate fractions.

The digestibility of fraction no. I (lactose and glucose) was the same for both diets: $96 \%$ of it was already digested at the end of the ileum and the faecal digestibility coefficient of $\mathrm{r} \cdot \mathrm{O}$ indicated that digestion was completed in the large intestine.

In the ileal digesta of calves on both diets oligosaccharides were found, composed of galactose and glucose, probably synthesized in the small intestine, as endogenous 
Table 6. Faecal digestibility coefficients of the different carbohydrate fractions and of their constituent sugars for two veal calves given milk-substitute diets* with and without $300 \mathrm{~g}$ yeast $/ k g$

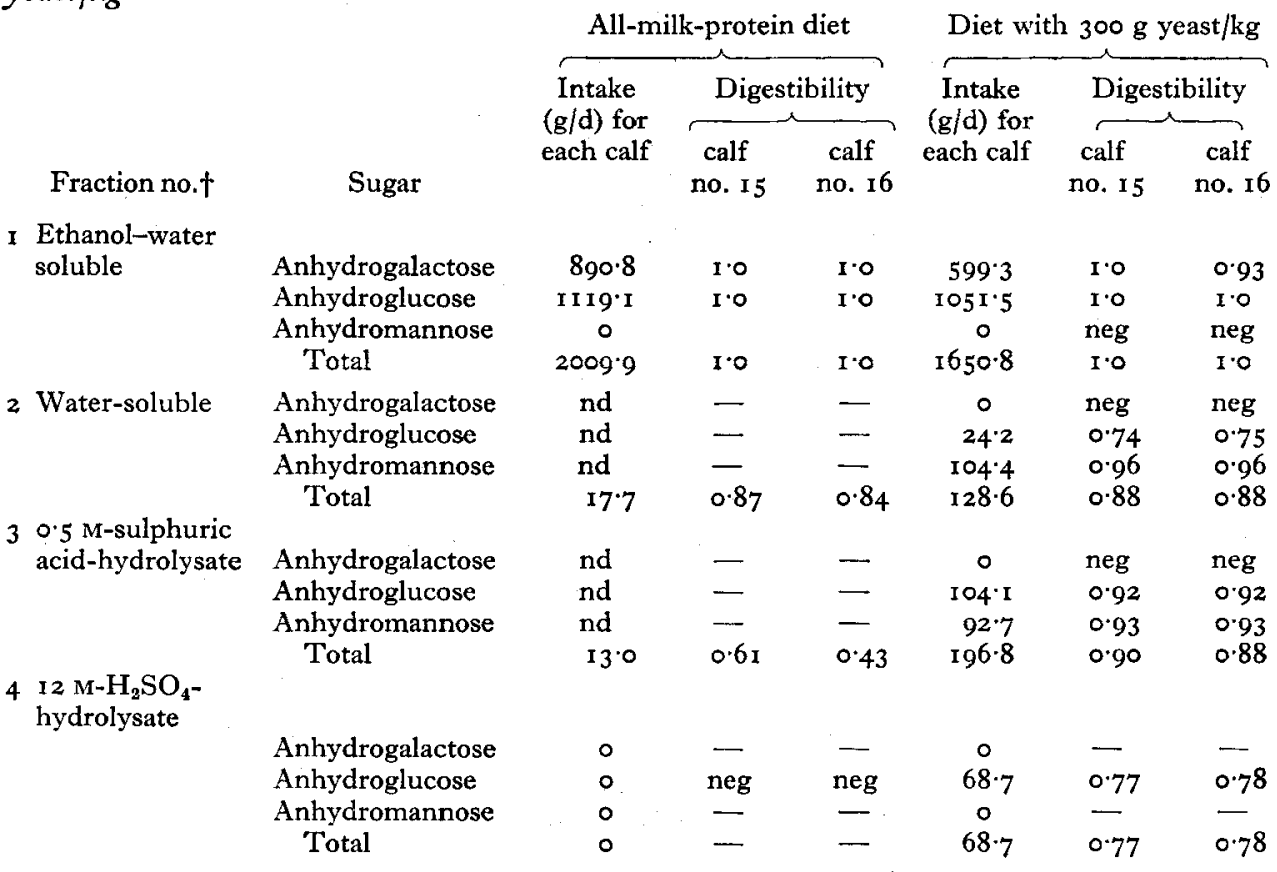

neg, negligible secretion of this sugar into the gastrointestinal tract; nd, not determined

* For details, see Table I.

+ For details of fractions and fractionation procedure, see Fig. I.

secretion of these oligosaccharides with mucus or other secreta is not likely. Synthesis of these oligosaccharides by the action of lactase ( $\beta$-galactosidase; $E C$ 3.2.x.23) on lactose in vitro was reported by Roberts $\&$ McFarren (1953). These oligosaccharides are broken down by bacterial enzymes in the large intestine. With the yeast diet some mannose was also found in the ethanol-soluble fractions of digesta and faeces.

Total faecal digestibilities of yeast-carbohydrates (fractions nos. 2, 3 and 4 from the yeast diet), were the same for the two calves. The average values for fractions nos. 2 and 3 were similar $(0.88$ and 0.89 respectively). The digestibility coefficient of fraction no. 4 was only 0.77 .

The digestibilities at the end of the ileum varied considerably between calves, but the average values were low for all fractions. When the average digestibility of total yeast-carbohydrates was calculated from the amounts in each fraction and their respective digestibilities, we found at the end of the ileum a value of $0.39(0.53$ and 0.25 for calves nos. 15 and 16 respectively) and a faecal digestibility coefficient of 0.87 .

These results confirmed the calculated digestibilities of the yeast-NFE (Table 3; average values for ileal and faecal digestibilities 0.26 and 0.92 respectively), and indicated that with veal calves the yeast cell wall polysaccharides are only slightly broken down, if at all, by the normal digestive enzymes in the calf's small in testine, 
but are used as substrates by the bacterial flora which are mainly concentrated in the large intestine as with other simple-stomached animals. This bacterial carbohydrate fermentation is accompanied by the production of acid, as was found in another experiment (van Weerden, unpublished results) where a decrease in $\mathrm{pH}$ of the contents of the large intestine was found when diets with yeast were given.

As regards the total digestibilities of the individual polysaccharides, it seems that in the water-soluble fraction no. 2 the glucan was less well digested than the mannan (average values 0.74 and 0.96 respectively). The glucan in fraction no. 4 also had a lower digestibility (average value 0.77 ). In fraction no. 3 , however, the digestibilities of the glucan and the mannan were the same (average values 0.92 and 0.93 respectively). One should realize, though, that the results mentioned are net results. Carbohydrates from the diet disappear, but carbohydrates in glycoproteins from mucus are added to the digesta.

Galactose and mannose are common constituents of the glycoproteins in the mucus from the stomach. But as these sugars were also present in the diets it is not possible to tell how much originated from mucus or from the diet. However, in fraction no. I of the diets mannose was absent whereas in this fraction of the ileal digesta of the calves on the yeast diet an average of $\mathbf{2 2} \mathrm{g}$ of this sugar was found, which could originate from glycoproteins, causing the negative digestibility. These glycoproteins must have contained some galactose also and therefore the true digestibility of the galactose in this fraction must have been higher than the apparent digestibility found. It is strange though that no mannose was found in fraction no. I of the ileal digesta of the calves on the all-milk-protein diet. It is also questionable whether glycoproteins or even glycopeptides would dissolve in ethanol-water $(80: 20, v / v)$. Another explanation of the presence of mannose in fraction no. I of the ileal digesta could be, that the mannan of the yeast was partly degraded to oligo-, di- or monosaccharides which were soluble in the ethanol-water mixture. In the faeces only about I $g$ of this mannose was left. As in general the amounts of sugars causing the negative digestibilities were never more than a few grams, we believe that the apparent digestibilities found were not very different from the true digestibilities.

The authors wish to thank Miss D. J. Honders and Ing. J. Huisman for technical assistance.

\section{REFERENCES}

Gropp, J. (1973a). Z. Tierphysiol. Tierernähr. Futtermittelk. 32, 84. Gropp, J. (1973b). Z. Tierphysiol. Tierernähr. Futtermittelk. 32, I44.

Gropp, J. (1973c). Z. Tierphysiol. Tierernähr. Futtermittelk. 32, 194.

Hagedorn, H. C. \& Jensen, B. N. (1923). Biochem. Z. 135, 46.

Huber, J. T., Jacobson, N. L., Allen, R. S. \& Hartman, P. A. (196r). F. Dairy Sci. 44, 1494.

Okamoto, M., Thomas, J. W. \& Johnson, T. L. (1959). F. Dairy Sci. 42, 920.

Roberts, H. R. \& McFarren, E. F. (1953). F. Dairy Sci. 36, 620.

Velu, J. G., Gardner, K. E. \& Kendall, K. A. (1959). Y. Dairy Sci. 42, 920.

Velu, J. G., Kendall, K. A. \& Gardner, K. E. (Ig6o). F. Dairy Sci. 43, 546. 